\title{
Professional Development and ICT: English Language Teachers' Voices
}

\author{
Lucas Kohnke \\ The Hong Kong Polytechnic University
}

\begin{abstract}
While technology use is becoming increasingly common in education, teachers remain reluctant to use technology and hesitant on how best to incorporate it into their teaching and practice. There is a strong demand from institutions for English language teachers to cope with the changing landscape of teaching in the twenty-first century. This explorative study investigated Hong Kong tertiary teachers' beliefs on continuing professional development activities to enhance their teaching. The study had a two-phase research design, with an initial questionnaire $(N=58)$ followed by semi-structured interviews $(N=12)$ to unpack the participants' hidden voices. The findings illustrated that most teachers are enthusiastic about professional development activities, though there is a misalignment between what universities value and reward and what teachers see as most beneficial for enhancing their teaching practices. The results suggested that professional development activities should focus on sharing good teaching practices (e.g., informal chats, mentoring) within universities rather than rewarding attending conferences and nonintegrated workshops.
\end{abstract}

Keywords: English language tertiary teachers, professional development, information communication technology, Hong Kong

Kohnke, L. (2021). Professional development and ICT: English language teachers' voices. Online Learning, 25(2), 36-53. https://doi.org/10.24059/olj.v25i2.2228

\section{Professional Development and ICT: English Language Teachers' Voices}

In the twenty-first century, most English language teachers and learners use technology (Healey, 2018) and teachers' pedagogical aptitudes for technology are key to the effective integration of technology into classrooms (Hubbard, 2018; Son, 2014). Therefore, teachers must take central roles as stakeholders and practitioners in mediating this development for personal and professional reasons (Son, 2018; Stockwell, 2018). Therefore, teachers engage with numerous modes of continuing professional development in technology tools and skills to improve their teaching, believing that these actions can enhance student-centered learning and inspire transformation for both teachers and students (Kessler \& Hubbard, 2018; Wang et al., 2020). Even though educational systems throughout the world encourage various professional development 
modes and activities, such as attending conferences, attending workshops, and conducting action research, teachers still hesitate to adopt technologies and lack confidence in using technology effectively in language teaching (Kessler, 2018; Shifflet \& Weilbacher, 2015; Tallvid, 2016).

As in other parts of the world, technology has become an integral part of learning and teaching in Hong Kong (Hyland \& Wong, 2013), and technology use continues to evolve as English language teachers both aspire and struggle to embrace it (Healey, 2018; Knobel \& Kalman, 2016; Stockwell, 2018). Therefore, it is problematic that language teachers have not embraced technology more successfully despite the heavy focus on professional development in technology skills and tools. Given the significance of continuing professional development, this explorative study investigated tertiary English language teachers' attitudes and beliefs concerning various continuing professional development modes in technology skills.

\section{Review of Relevant Literature}

Recent literature has established an increased need for professional development (DarlingHammond et al., 2017; Wasserman \& Migdal, 2019), and specifically technology-focused continuing professional development (Curwood, 2014), as teachers face new teaching and learning settings, including hybrid, flipped, synchronous and asynchronous environments (Healey, 2018; Kohnke \& Moorhouse, 2020). English language teachers engage in continuing professional development for both internal and external reasons. Professional development is often compulsory in education (Canagarajah, 2015; Crandall \& Christison, 2016). Traditionally, teachers must complete a specific number of hours of professional development each year to maintain certification. Depending on the school, teachers may or may not receive payment or time-release as incentives to attend such activities. Generally, teachers want to be up to date with the latest pedagogies to provide better education to their students. However, many teachers cannot afford professional development opportunities outside their schools, such as major English language teaching conferences or enrolling in courses, even if they have time to do so (Abbot et al., 2018). Thus, teachers must settle for the opportunities available in their schools or districts, which are often one-off workshops. Numerous studies have questioned the limitations of conventional modes of delivery, typified by these individual non-integrated workshops, to address a wide range of current professional development methods (Megginson \& Whitaker, 2017).

Moreover, researchers have found that a large proportion of professional developmenttargeted technology is woefully inadequate (Borko, 2004; McChesney \& Aldridge, 2018). Continuing professional development offerings vary considerably (Bowe \& Gore, 2016; Ling \& Mackenzie, 2015; Opfer \& Pedder, 2011), and teachers still cannot integrate technology pedagogically after taking part in development activities (Tondeur et al., 2016). Teachers continue to criticize professional development, as it has not allowed for the classroom's complex situation (Knobel \& Kalman, 2016). Thus, it is vital to identify suitable continuing professional development activities for tertiary teachers (Coldwell, 2017), and to provide deep and meaningful learning experiences situated in the teachers' contexts, so that teachers can gain the technological and pedagogical skills they need to teach twenty-first-century students (Cubeles \& Riu, 2018; Rijst et al., 2018). 


\section{English Language Teaching and Digital Pedagogy}

Numerous studies have stated the benefits of integrating technology for second language acquisition (e.g., interactivity, collaboration, authentic materials, independent learning) (CardenasClaros \& Oyanedel, 2015; Chapelle 2012; Stockwell, 2012). English language teaching and digital pedagogy take many forms, ranging from drill and practice of certain language skills, such as reading and writing, to using Web 2.0, augmented reality, and virtual reality to construct knowledge. Today's generation of learners has grown up surrounded by technology and they expect innovative tools and conceptual methods from their teachers.

Accordingly, teachers use a plethora of technology tools and online environments to adapt, personalize, and enhance the student learning experience and improve learning outcomes. Digital pedagogy is thus a vital component of teaching: teachers must meet this challenge and move beyond traditional pedagogical approaches and methods, as students access learning materials on their smart devices, and classrooms have interactive whiteboards, Mobile Computers on Wheels (MoCoWs) and Apple TVs. English language teachers' usage of technology to its fullest potential largely depends upon their ability to exploit it (Cabanatan, 2003). Accordingly, it is necessary to examine the current understanding of professional development to establish how current delivery methods are effective and consistent with evolving notions of teaching.

Teacher integration of technology has encountered internal and external barriers (Albion et al., 2015; Lowther et al., 2008; Vongkulluksn et al., 2018). Chiu and Churchill (2016) found that teachers could only incorporate technology and subsequent digital pedagogy when they had an overall understanding of it. Unfortunately, many continuing professional development activities still focus on retooling teachers: they do not actively engage teachers, they simply focus on developing competencies in one specific type of information communication technologies (ICT) application (Koh et al., 2016; Tondeur et al., 2015). Thus, continuing professional development needs to focus on teachers' attitudes and beliefs and enhance their competency to exploit technology fully (Starkey, 2020). Recently, there has been more stress on the importance of continuing professional development, focusing on pedagogy and not on the technology itself (Hubbard, 2018; Prestridge, 2014). This change is a move in the right direction, as teachers need to use the technology separately and do so in accordance with the curriculum.

\section{Teacher Beliefs and the Link with Technology Practice}

Earlier studies have discussed teachers' pedagogical beliefs as direct determiners of how teachers use ICT in the classroom (Eickelmann \& Vennemann, 2017; Jääskelä et al., 2017; Lawrence, 2018; Tondeur et al., 2017). Kagan (1992) argued that teachers' pedagogical beliefs help them to filter new information and experience for significance. Similarly, teachers apply previous experience with technology when they use new techniques and practices (Hsu, 2016; Sang et al., 2010). Teachers' thoughts on adopting new pedagogies with technology also match what they believe fits in with good teaching and effective education (Ertmer et al., 2015; Sullivan \& Yang, 2018). There is a direct correlation between sound integration of ICT in the classroom and teachers' attitudes towards it (Ertmer \& Ottenbreit-Leftwich, 2013; Hur et al., 2016). Ertmer et al. (2015) established that certain teachers who hold constructivist beliefs use technology more with their students. As beliefs are an integral part of successful classroom integration of ICT, this recognition is a vital aspect of any approach to professional development. 


\section{The Study}

Given the importance of continuing professional development as an essential part of enhancing teachers' competency in utilizing technology in their practice, teachers continue to hesitate, aspire, and struggle to embrace technology after taking part in professional development activities. Additional research is warranted to understand teachers' beliefs and attitudes towards professional development activities. The study explored the question:

RQ: What are Hong Kong tertiary English teachers' attitudes and beliefs towards various modes of professional development in ICT skills to enhance their teaching?

\section{Methods}

The author adopted an explorative qualitative approach by collecting two types of data in two phases. The first phase, a questionnaire $(N=58)$, provided an overall picture of the research problem, and it informed the data collection in Phase 2, in which semi-structured interviews took place (Ivankova et al., 2006). After this, an analysis of the relevant qualitative data and semistructured interviews $(N=12)$ allowed me to refine the previous results, given the ability to interrogate participants' views and to unpack their hidden voices in a more fluid manner (Creswell, 2009; Rossman \& Wilson, 1985; Tashakkori \& Teddlie, 1998) to create a holistic understanding of their views.

This study is positioned within an interpretive framework that holds the ontological position that reality is a subjective phenomenon co-constructed through an individual's experience and social interactions; therefore, the experience needs to be understood within its particular context (Crotty, 1998).

\section{Participants}

I used convenience sampling for this study, as it appeared that this method could produce participants who were representative of the wider population of English language teachers at tertiary institutions in Hong Kong. I contacted the English language centers at the seven University Grants Committee (UGC) funded universities in Hong Kong and received consent to access the research participants. An invitation e-mail went to all tertiary teachers at these English language centers to invite them to participate in the online questionnaire. A total of 58 English language teachers at seven tertiary institutions in Hong Kong participated in this study.

Of the 58 teachers who completed the questionnaire, I selected 12 teachers to participate in the follow-up semi-structured interviews based on their comparable professional development (PD) experience levels in Hong Kong to represent the seven language centers. Table 1 outlines the demographics of the 12 interview participants: seven male and five female teachers. They differed in length of teaching experience, ranging from 8 to 25 years, and academic rank, varying from instructor to senior lecturer. I obtained written consent from all participants, and participants received pseudonyms to safeguard their anonymity. 
Table 1

Demographics of Interviewee Participants $(\mathrm{N}=12)$

\begin{tabular}{cccc}
\hline$\#$ & Pseudonym & Academic Rank & \# Years of Teaching Experience \\
\hline T1 & Harry & Instructor & 15 \\
T2 & Noah & Instructor & 8 \\
T3 & Linda & Instructor & 16 \\
T4 & Sophia & Instructor & 6 \\
T5 & Jonathan & Lecturer & 18 \\
T6 & Anthony & Lecturer & 20 \\
T7 & Oliver & Lecturer & 10 \\
T8 & Chloe & Teaching Fellow & 11 \\
T9 & George & Senior Lecturer & 25 \\
T10 & Mitch & Senior Lecturer & 14 \\
T11 & Anna & Senior Lecturer & 16 \\
T12 & Melina & Associate Professor & 25 \\
\hline
\end{tabular}

\section{Procedures and Data Collection}

I used SurveyMonkey to administer the questionnaire. It established the frequency of engagement in professional development in ICT skills for teachers. I hoped that this would provide initial ideas for further exploration in the interview segment. The questions were adaptations from Kohnke's (2018) and Mak's (2010) studies of ESL teachers' professional development needs in Hong Kong. Five English language teachers who did not participate in the study piloted the questionnaire, and they provided feedback on individual items, instructions, visual layout, potential ambiguities of problematic wording, platform, and complexity. I analyzed their responses and deleted or rephrased questions to eliminate ambiguities as a step towards finalizing the questionnaire (see Appendix A) (Dörnyei, 2015).

In the second phase, I conducted one-on-one semi-structured interviews (See Appendix B for questions) with 12 participants, lasting between 24 and 39 minutes. Following the interpretive paradigm, I assumed that a thorough interrogation of the rich and multifaceted description of the nature of professional development in relation to ICT would be possible within the framework of the semi-structured interviews, as Kvale (2007) demonstrated. Credibility in interpretive studies is measured by how well the participants' portrayal matches their perceptions (Bloomberg \& Volpe, 2008). Participants had the opportunity to review their interview transcripts and results and discussion and remove any comments through the two member checks.

\section{Data Analysis}

I analyzed the data for this two-phase study inductively following the interpretive paradigm (Carter \& Little, 2007). I analyzed the first phase, the online questionnaire, using descriptive statistics via the Statistical Package for the Social Sciences (SPSS) software. In the second phase, 
I used thematic analysis to provide a rich, detailed, and complex account of the data (Braun \& Clarke, 2006). I transcribed, coded, and categorized the interviews by hand to maintain and allow closeness to the data. I tried to capture the experiences, perspectives, voices, and meanings of the participants in accordance with interpretive studies. However, being a practicing teacher embedded within the context of this particular group enabled me to share experience and possibly gain insight into the emotions and reactions of the teachers themselves during the interviews. As researchers, we are an inescapable part of the world we are researching (Bishop \& Shephard, 2011).

\section{Limitations}

While the current study sheds light on the English language teachers' experiences at tertiary institutions in Hong Kong and beyond, the results have limitations. First, the results emerged from a questionnaire with 58 teachers and 12 interviews. Although the sample size is moderately small, small sample sizes are quite common in qualitative studies. However, the sample size for this study included English language teachers from all of the UGC universities in Hong Kong, and as such, the sample is purposely chosen to make sense of what is happening (Guba \& Lincoln, 1989). Another limitation of this study is that participants who volunteered to participate might be more involved in PD or hold a strong or negative attitude to PD and ICT, which may have biased the findings. Therefore, further investigation with a larger sample is required to reveal the relationship between attitude and behavior. Moreover, additional participants and decision-makers' views and perspectives would have added more breadth to this study. It is left to the reader to position themselves vis-à-vis the research, deciding the relevance and value to their context (Merriam \& Grenier, 2019).

\section{Results and Discussion}

The study explores Hong Kong tertiary teachers' beliefs on continuing professional development activities to enhance their teaching. In the discussion below, I discuss excerpts from the interviews to exemplify the participants' experiences and reveal the complexity of their professional development, thereby providing a thick description in their own words of their encounter with a variety of professional development modes.

The findings from the questionnaire and the semi-structured interviews revealed that participants preferred to use certain professional development modes. Table 2 summarizes the survey responses of the five subquestions regarding engagement in professional development activities. The mean scores for Item 1 (conducting action research into ICT skills) and Item 5 (participating in a community of practice) were less than 2, indicating that participants engaged in these two professional development activities less often. The mean scores for Item 2 (attending conferences, workshops, seminars, or courses in ICT skills), Item 3 (reading professional literature involving ICT, for example, journals, evidence-based papers, and thesis papers), and Item 4 (sharing good teaching practice, for example, mentoring, informal dialogues, lesson planning, and peer observation and use/adoption of ICT with colleagues) were greater than 2 , indicating that participants engaged in these three professional development activities moderately often. Conducting action research into ICT skills (Item 1, $M=1.26$ ) was the least engaged-in professional development activity, and sharing good teaching practice in the use/adoption of ICT with colleagues was the most engaged-in professional development activity (Item $4, M=2.64$ ). 
Table 2

Engagement in Professional Development Activities (Q7)

\begin{tabular}{lcccccc}
\hline \multicolumn{7}{c}{ Frequency Count (\%) of Survey Responses } \\
\hline \multicolumn{1}{c}{ Item } & $\mathbf{0}$ & $\mathbf{1}$ & $\mathbf{2}$ & $\mathbf{3}$ & $\mathbf{4}$ & M (SD) \\
\hline $\begin{array}{l}1=\text { Conducting } \\
\text { action research }\end{array}$ & $22(37.9 \%)$ & $13(22.4 \%)$ & $11(19.0 \%)$ & $10(17.2 \%)$ & $2(3.4 \%)$ & $1.26(1.24)$ \\
$\begin{array}{l}2=\text { Attending } \\
\text { events }\end{array}$ & $5(8.6 \%)$ & $15(25.9 \%)$ & $16(27.6 \%)$ & $13(22.4 \%)$ & $9(15.5 \%)$ & $2.10(1.21)$ \\
$\begin{array}{l}3=\text { Reading } \\
\text { literature }\end{array}$ & $10(17.2 \%)$ & $9(15.5 \%)$ & $12(20.7 \%)$ & $17(29.3 \%)$ & $10(17.2 \%)$ & $2.14(1.36)$ \\
$\begin{array}{l}4=\text { Sharing } \\
\text { good practices }\end{array}$ & $4(6.9 \%)$ & $6(10.3 \%)$ & $14(24.1 \%)$ & $17(29.3 \%)$ & $17(29.3 \%)$ & $2.64(1.21)$ \\
$\begin{array}{l}5=\text { Joining } \\
\text { communities }\end{array}$ & $16(27.6 \%)$ & $9(15.5 \%)$ & $14(24.1 \%)$ & $8(13.8 \%)$ & $11(19.0 \%)$ & $1.81(1.47)$ \\
\hline
\end{tabular}

Note. $0=$ never, $1=$ once every $2-3$ years, $2=$ once every year, $3=2-3$ times a year, and $4=$ more than three times a year.

While it is not surprising that teachers can engage in a wide range of professional development activities, as earlier studies have confirmed (Darling-Hammond et al., 2017; Desimone \& Garet, 2015), it is notable from the questionnaire results that there is a clear preference for collaborative sharing with colleagues. This preference became especially clear during the interviews, where participants revealed that they felt a sense of belonging in their peer groups, and in stark contrast to presenting at conferences in unfamiliar settings, their sense of personal identity compelled them to engage most frequently in this type of continuing professional development (Prestridge \& Tondeur, 2015; Tondeur et al., 2016).

\section{Sharing Good Teaching Practice}

In contrast to more formal conferences (e.g., IATEFL, TESOL), participants saw sharing good teaching practice ICT as the most useful ICT skill for enhancing their teaching. Participants especially found sharing sessions relevant, well planned, and immediately applicable to their teaching context, and they appreciated the interpersonal interactions. Melina explained why she is attending an upcoming in-house sharing session: "one colleague invited me. She is interested. So, she invited me to join because it's like a group collaboration." Moreover, eight teachers found sharing sessions more relevant, and they perceived them as immediately applicable to their teaching. For instance, as Noah revealed,

It's good to see what other colleagues do and how they approach things. So, the most recent one I went to was the business one, although I don't teach business, but I just wanted to see, okay, what do they do in business, how do they incorporate technology in the classes? How do they handle certain problems? Do they do more writing, or do they do more speaking? And how do they collaborate with the business department?

Another common impetus for sharing sessions is for colleagues to share recent pedagogy or tools they have tried out. Anthony indicated that he likes to attend because "I always advocate, this kind 
of thing, like a hands-on workshop, that you-maybe it's just a computer lab or maybe it's a place you-you go there and-and do something. And that's how I can learn something."

It was common for interviewees to seek out colleagues informally to chat about how to use ICT or about where they could try something new in a collaborative environment. The findings are generally in line with previous research, which found that collaboration among equals was a key factor for successful professional development (Appova \& Arbaugh, 2018; de Laat \& Schreurs, 2013; Eraut, 2011).

Another aspect highlighted by participants was the possibility of attaining practical experience with technology, which was something for which numerous participants expressed a desire. The interview responses also showed that most of their practical experience came from their colleagues and informally organized sessions. The interviews revealed that English language teachers need practical application training to use new forms of ICT and see how they might fit what they learned in with their teaching. Son and Windeatt (2017) argued that today's English language teaching is as important as the use of ICT, as it provides multiple authentic language teaching and learning opportunities.

\section{Community of Practice}

Several of the interviewees brought up the community of practice, but they were not convinced of its value. Though it should ideally fall into the more informal category of professional development activities, most interviewees did not experience it this way. As Anna expressed, "community of practice in Hong Kong is very bureaucratic: you have to apply, sign up, [and] attend session[s] at specific time-slots. It is just too formal." In a similar vein, George said,

If the community is open and they're willing to share-and they're willing to be honest, you know, like-like counter these problems-I think it's good. But uh, if the c- if the group is very, you know, worried or very careful-or they're, you know, worried about you know looking bad-then I think maybe that it's not as good.

However, in Hong Kong, as almost all the interviewees mentioned, there is much higher anxiety about face threats when dealing with those outside peer groups. Wider networks tend to comprise teachers who do not necessarily already know each other or otherwise possess any personal ties whatsoever. Therefore, I hypothesized that this leads to particular groupings, where instructors from different institutions are less satisfactory for participants. The findings run counter to the conventional views that community of practice is meaningful and relevant to individual members, and it is at odds with the findings of Parker and Patton (2017) in which the community of practice was found to be a foundation for collaboration and improved teaching practice.

\section{Attending Conferences}

This study provides evidence that teachers enjoy attending conferences, workshops, seminars, or ICT skills courses. For instance, as Linda revealed, "I love going to conferences and workshops; you can often pick up something new in tech to use in your classroom." However, many teachers tend to do so out of pressure to attend and collect certificates: "I think generally, you know we have the appraisal system, and that's always a place where you can show your certificates for the-for PD work you've done" (Mitch). This finding concurs with previous studies (Teräs, 2016) in which teachers seemed to attend professional development activities their institutions valued and rewarded. It became evident in the interviews that the institutions value 
traditional types of professional development activities in ICT skills, they consider them useful, and they expect teachers to attend.

Several teachers stated that they enjoy attending conferences, but often they do not consider them useful for enhancing their teaching. Neil explained: "I enjoy going to conferences, but actually, I rarely get anything out of it that I can incorporate in my own classrooms. They are really good to catch up with friends." Thus, the outcome from an institutional point of view, clearly articulated by the teachers, was their mere presence, rather than any sort of transformational change due to their attendance and/or presentation at the conference. The essence of continuing professional development is to include practical and realistic opportunities to use in the language classroom (Eaton et al., 2018).

\section{Action Research}

Conducting action research into ICT skills was a rarely used professional development mode. Several interviewees mentioned action research as something that would benefit both the students and the instructors, but they saw it equally as something that falls almost entirely on the teachers' shoulders to plan, implement, and reflect on. One participant, Harry, highlighted the time demands of action research and how this was necessarily incompatible with his schedule.

I mean, action research for instance, um, you know, usually, you know, when- when- when you identify a problem in class, you know, and you decided, you know, and you decided to do something about it, then it is often too late before the semester is over.

Despite the high potential for reflective practice action research affords, many see it as over and above what instructors are already responsible for in their normal day-to-day teaching. Thus, teachers do not consider it a useful continuing professional development mode for enhancing their teaching.

\section{Reading Professional Literature}

It emerged that teachers read professional literature frequently. This finding is not surprising, as teachers by nature are interested in education, and many respondents expressed a genuine desire to read and understand the current best-practice trends in the field. According to Evelyn, "I think reading is something that we don't often talk about, but that is the foundation of professional development, which can be done anywhere, anytime together with other people, in special interest groups, or in even talking alone." Harry also mentioned that he gains inspiration from reading, but he came at it from a different angle:

Hmm. Um, I don't quite read a lot of journals, unless, for example, uh, they're like LinkedIn. That there's an article platform, then I feel that-that I'm interested in that, but only they're not quite academic, uh, articles. They're like, um, uh- uh- uh, some like magazine type of article, but they are more practical, yes, so I read.

Interestingly, there is a tacit acknowledgment that many see this as a less institutionally valued form of professional development. Interviewees brought up the importance of collecting evidence to demonstrate their curricular practical training activities over the academic year. Although they found reading essential, it was something they could not quantify to the administration. Teachers appeared to see PD only from the perspective of what they could present to the administration. It also stands in contrast to other studies, which show that professional development activities should focus on the knowledge, beliefs, and praxis of teachers, and this is broadly in line with the findings of Opfer and Pedder (2011), echoed by Patton et al. (2015). These 
studies found that the teachers and the school need to engage in meaningful discussion, and professional development needs to interact with all stakeholders to help teachers improve their existing practice.

\section{Conclusion and Implications}

This study has found that teachers favored more informal types of continuing professional development, such as sharing good teaching practice in the use/adoption of ICT with colleagues for enhancing their existing teaching practice. Teachers are interested in developing as professionals, especially as competencies in ICT skills and tools are becoming increasingly important in the language classroom (Hubbard, 2018; Son, 2014). Language teachers can no longer avoid integrating technology in their classrooms, as tertiary institutions are increasingly adopting blended and hybrid forms of learning. These changes place many pedagogical demands on teachers who need practical application and technical skills to see how technology may fit their teaching. Communication is at the heart of language teaching, and as this study has shown, teachers would like to use technology and attend a variety of PD modes to improve their teaching practice.

In terms of professional development modes, informal collaboration remains a driving force behind much of the professional development in which teachers productively engage and which they find useful in enhancing their teaching and learning practice. In these settings, teachers appear more comfortable with sharing and learning among equals. One such setting is informal mentoring, where the mentee and mentor can support and encourage each other while transforming their teaching practice in a mutually supportive network (Kohnke, 2020). This setting is a fruitful avenue to explore, as it appears to help teachers gain better insights into how to incorporate pedagogy around English language teaching and technology in education, which could help inform teachers' practice.

However, the study also revealed a misalignment between what teachers considered effective continuing professional development and what universities valued and rewarded, and thus, teachers felt forced to divert some of their energy to less useful continuing professional development modes. It is necessary to consider more carefully how institutional expectations of continuing professional development are shaping higher education. In particular, more attention might go towards viewpoints, and directions from actual teachers and what they consider are their needs for the shifting landscape of increased interactivity and mobility that ICT brings to language classrooms (Kessler \& Hubbard, 2018; Liao et al., 2017).

In summary, this study makes an important contribution to professional development as it highlights the disconnect between administrators awarding development credits and teachers who must earn them. Effective professional development cannot be optimized without communication between the teacher and institutions. Administrators need to allow teachers to become more actively involved in deciding their pedagogic goals and how best to achieve them through the effective use of ICT so that the transfer of skills and knowledge around pedagogy, English language teaching, and technology in education improves. 


\section{References}

Abbot, M. L., Lee, K. K., \& Rossiter, M.J. (2018). Evaluating the effectiveness and functionality of professional learning communities in adult ESL programs. TESL Canada Journal, $35(2), 1-25$.

Albion, P. R., Tondeur, J., Forkosh-Baruch, A., \& Peeraer, J. (2015). Teachers' professional development for ICT integration: Towards a reciprocal relationship between research and practice. Education and Information Technologies, 20(4), 655-673.

Appova, A., \& Arbaugh, F. (2018). Teachers' motivation to learn: Implications for supporting professional growth. Professional Development in Education, 44(1), 5-21.

Bishop, E. C. \& Shephard, M. L. (2011). Ethical reflections: Examining reflexivity through the narrative paradigm. Qualitative Health Research, 21(9), 1283-1294.

Bloomberg, L. \& Volpe, M. (2008). Completing your qualitative dissertation: A road map from beginning to end. Sage.

Borko, H. (2004). Professional development and teacher learning: Mapping the terrain. Educational Researcher, 33(8), 3-15.

Bowe, J., \& Gore, J. (2016). Reassembling teacher professional development: The case for quality teaching rounds. Teacher and Teaching: Theory and Practice, 23, 352-366.

Braun, V., \& Clarke, V. (2006). Using thematic analysis in psychology. Qualitative Research in Psychology, 3(2), 77-101.

Cabanatan, P. (2003, June 18-20). Integrating pedagogy and technology: The SEAMEO INNOTECH experience. Experts Meeting on Teachers'/Facilitators' Training in Technology-Pedagogy Integration, Bangkok, Thailand.

Canagarajah, S. (2015). Translingual practice: Global Englishes and cosmopolitan relations. Routledge.

Cardenas-Claros, M., \& Oyanedel, M. (2015). Teachers' implicit theories and use of ICTs in the language classroom. Technology, Pedagogy and Education, 25(2), 207-225.

Carter, S. M., \& Little, M. (2007). Justifying knowledge, justifying method, taking action: Epistemologies, methodologies, and methods in qualitative research. Qualitative Health Research, 17, 1316-1328.

Chapelle, C. A. (2012). Computer assisted language teaching and testing. In M. Long \& C. Doughty (Eds.), Handbook of second and foreign language teaching. Blackwell. 
Chiu, T. K. F., \& Churchill, D. (2016). Adoption of mobile devices in teaching: Changes in teacher beliefs, attitudes and anxiety. Interactive Learning Environments, 24(2), 317-327.

Coldwell, M. (2017). Exploring the influence of professional development on teacher careers: A path model approach. Teaching and Teacher Education, 61, 189-198.

Crandall, J., \& Christison, M. A. (2016). Teacher education and professional development in TESOL: Global perspectives. Routledge.

Creswell, J. W. (2009). Research design: Qualitative, quantitative, and mixed methods approaches (3rd ed.). Sage.

Crotty, M. (1998). The foundations of social research: Meaning and perspective in the research process. Sage.

Cubeles, A., \& Riu, D. (2018). The effective integration of ICTs in universities: The role of knowledge and academic experience of professors. Technology, Pedagogy and Education, 27, 339-349.

Curwood, J. S. (2014). English teachers' cultural models about technology. Journal of Literacy Research, 46(1), 9-38.

Darling-Hammond, L., Hyler, M. E., \& Gardner, M. (2017). Effective teacher professional development. Learning Policy Institute.

De Laat, M., \& Schreurs, B. (2013). Visualizing informal professional development networks: Building a case for learning analytics in the workplace. American Behavioral Scientist, $57,1421-1438$.

Desimone, L. M., \& Garet, M. S. (2015). Best practices in teachers' professional development in the United States. Psychology, Society, \& Education, 7(3), 252-263.

Dörnyei, Z. (2015). Research methods in applied linguistics. Oxford University Press.

Eaton, S. E., Wagner, S., Hirashiki, J., \& Ciancio, J. (2018). Understanding and exploring signature pedagogies for TESOL teacher education. University of Calgary Press.

Eickelmann, B., \& Vennemann, M. (2017). Teachers' attitudes and beliefs regarding ICT in teaching and learning in European countries. European Research Journal, 16, 733-761.

Eraut, M. (2011). Informal learning in the workplace: Evidence on the real value of work-based learning (WBL). Development and Learning in Organizations: An International Journal, $25(5), 8-12$. 
Ertmer, P. A., \& Ottenbreit-Leftwich, A. (2013). Removing obstacles to the pedagogical change required by Jonassen's vision of authentic technology-enabled learning. Computers \& Education, 64, 175-182.

Ertmer, P. A., Ottenbreit-Leftwich, A., \& Tondeur, J. (2015). Teacher beliefs and uses of technology to support 21 st century teaching and learning. In H. R. Fives, \& M. Gill (Eds.), International handbook of research on teacher beliefs (pp. 403-418). RoutledgeTaylor \& Francis.

Healey, D. (2018). Technology enhanced learning environments. In The TESOL encyclopedia of English language teaching. John Wiley \& Sons, Inc.

doi:10.1002/9781118784235.eelt0437

Hsu, P. (2016). Examining current beliefs, practices and barriers about technology integration: A case study. TechTrends: Linking Research \& Practice to Improve Learning, 60(1), 30-40.

Hubbard, P. (2018). Technology and professional development. In The TESOL encyclopedia of English language teaching. John Wiley \& Sons, Inc.

doi:10.1002/9781118784235.eelt0426

Hur, J. W., Shannon, D., \& Wolf, S. (2016). An investigation of relationships between internal and external factors affecting technology integration in classrooms. Journal of Digital Learning in Teacher Education, 32(3), 105-114.

Hyland, K., \& Wong, L. C. (2013). Innovation and change in English language education. Routledge.

Ivankova, N. V., Creswell, J. W., \& Stick, S. L. (2006). Using mixed-methods sequential explanatory design: From theory to practice. Field Methods, 18(1), 3-20.

Jääskelä, P., Häkkinen, P., \& Rasku-Puttonen, H. (2017). Teacher belief regarding learning, pedagogy, and the use of technology in higher education. Journal of Research on Technology in Education, 49(3-4), 198-211.

Kagan, D. M. (1992). Professional growth among preservice and beginning teachers. Review of Educational Research, 62(2), 129-169.

Kessler, G. (2018). Technology and the future of language teaching. Foreign Language Annals, 51(1), 205-218.

Kessler, G., \& Hubbard, P. (2018). Language teacher education and technology. In C. A. Chapelle \& S. Sauro (Eds), Handbook of technology and second language teaching and learning (pp. 278-292). John Wiley \& Sons, Inc.

Knobel, M., \& Kalman, J. (2016). New literacies and teacher learning: Professional development and the digital turn. Peter Lang. 
Koh, J. W. L., Chai, S. C., \& Lim, W. Y. (2016). Teacher professional development for TPACK$21 \mathrm{CL}$, effects on teacher ICT integration and student outcomes. Journal of Educational Computing Research, 55(2), 172-196.

Kohnke, L. (2018). Professional digital competence and professional development among higher education teachers: An explorative survey. Proceedings of the 5th International Foreign Language Learning and Teaching Conference, 80-89.

Kohnke, L. (2020). Mentoring in the online sphere: A case study of EAP teachers. Teacher Development Academic Journal, 1(1), 30-43.

Kvale, S. (2007). Doing interviews. Sage.

Lawrence, G. (2018). The role of language teacher beliefs in an increasingly digitalized communicative world. IGI Global.

Ling, L. M., \& Mackenzie, N. (2015). An Australian perspective on teacher professional development in supercomplex times. Psychology, Society, and Education, 7(3), 264-278.

Liu, K.Y. (2012). A design framework for online teacher professional development. Asia Pacific Education Review, 13(4), 701-711.

Lowther, D., Inan, F., Strahl, J., \& Ross, S. (2008). Does technology integration "work" when key barriers are removed? Educational Media International, 45(3), 195-213.

Mak, B. (2010). The professional development needs of Hong Kong ESL teachers. Asia Pacific Educational Review, 11(3), 397-410.

McChesney, K., \& Aldridge, J. M. (2018). A review of practitioner-led evaluation of teacher professional development: Professional development in education. Teacher Development, 22(2), 22314-338. doi:10.1080/19415257.2018.1452782

Megginson, D., \& Whitaker, V. (2017). Continuing professional development (2nd ed.). Chartered Institute of Personnel and Development.

Merriam, S. B. \& Grenier, R.S. (2019). Qualitative research in practice: Examples for discussion and analysis. John Wiley \& Sons.

Opfer, V. D., \& Pedder, D. (2011). Conceptualizing teacher professional learning. Review of Educational Research, 81, 376-407.

Parker, M., \& Patton, K. (2017). What research tells us about effective continuing professional development for physical education teachers. In C. D. Ennis (Ed.), Routledge handbook of physical education pedagogies (pp. 447-460). Taylor \& Francis. 
Patton, K., Parker, M., \& Tannehill, D. (2015). Helping teachers help themselves: Professional development that makes a difference. NASSP Bulletin, 99(1), 26-42.

Prestridge, S. (2014). Reflective blogging as part of ICT professional development to support pedagogical change. Australian Journal of Teacher Education, 39(2), 70-86.

Prestridge, S., \& Tondeur, J. (2015). Exploring elements that support teachers' engagement in online professional development. Education Science, 5(3), 119-219.

Rijst, R., Baggen, Y., \& Sjoer, E. (2018). University teachers' learning path during technological innovation in education. International Journal for Academic Development. https://doi.org/10.1080/1360144X.2018.1500916

Rossman, G. B., \& Wilson, B. L. (1985). Numbers and words: Combing quantitative and qualitative methods in a single large-scale evaluation study. Evaluation Review, 9, 627643.

Sang, G., Valcke, M., Braak, J., \& Tondeur, J. (2010). Student teachers' thinking processes and ICT integration: Predictors of prospective teaching behaviors with educational technology. Computer and Education, 54(1), 103-112.

Shifflet, R., \& Weilbacher, G. (2015). Teacher beliefs and their influence on technology use: A case study. Contemporary Issues in Technology and Teacher Education (CITE Journal), $15,368-394$.

Son, J. B. (2014). Moving beyond basics: From CALL coursework to classroom practice and professional development. In Computer-assisted language learning: Learners, teachers, and tools (pp. 122-149). Cambridge Scholars Publishing.

Son, J. B. (2018). Teacher development in technology-enhanced language teaching. Palgrave Macmillan.

Son, J. B., \& Windeatt, S. (2017). Language teacher education and technology. Bloomsbury Academic.

Starkey, L. (2020). A review of research exploring teacher preparation for the digital age. Cambridge Journal of Education, 50(1), 37-56.

Stockwell, G. (2012). Computer-assisted language learning: Diversity in research and practice. Cambridge University Press.

Stockwell, G. (2018). Mobile assisted language learning: Concepts, contexts \& challenges. Cambridge University Press. 
Sullivan, R., Neu, V., \& Yang, F. (2018). Faculty development to promote effective instructional technology integration: A qualitative examination of reflections in an online community. Online Learning, 22(4), 341-359. doi:10.24059/olj.v22i4.1373

Tallvid, M. (2016). Understanding teachers' reluctance to the pedagogical use of ICT in 1:1 classrooms. Education and Information Technologies, 21, 503-519.

Tashakkori, A., \& Teddlie, C. (1998). Mixed methodology: Combining qualitative and quantitative approaches (vol. 46). Sage.

Teräs, H, (2016). Collaborative online professional development for teachers in higher education. Professional Development in Education, 42(2), 258-275.

Tondeur, J., Aesaert, K., Pynoo, B., Braak, J. Frayman, N., \& Erstad, O. (2015). Developing a validated instrument to measure preservice teachers' ICT competencies: Meeting the demands of the 21st century. British Journal of Educational Technology, 48(2), 462-472.

Tondeur, J., Fokosh-Baruch, A., Prestridge, S., Albion, P., \& Edirisinghe, S. (2016). Responding to challenges in teacher professional development for ICT integration in education. Journal of Educational Technology \& Society, 19(3), 110-120.

Tondeur, J., van Braak, J., Ertmer, P. A., \& Ottenbreit-Leftwich, A. (2017). Understanding the relationship between teachers' pedagogical beliefs and technology use in education: A systematic review of qualitative evidence. Educational Technology Research and Development, 65, 555-575.

Vongkulluksn, V., Xie, K., \& Bowman, M. (2018). The role of value on teachers' internalization of external barriers and externalization of personal beliefs for classroom technology integration. Computers \& Education, 118(2), 70-81.

Wang, X., Jacbo, J.W., Blakesley, C.C., Xiang, W., Ye, H., Xu, S., \& Lu. F. (2020). Optimal professional development ICT training indicatives at flagship universities. Education and Information Technologies, 25, 4397-4416.

Wasserman, E., \& Migdal, R. (2019). Professional development: Teachers' attitudes in online and traditional training course. Online Learning, 23(1), 132-143. doi:10.24059/olj.v23i1.1299

Wilson, N., \& McLean, S. (1994). Questionnaire design: A practical introduction.: University of Ulster Press. 


\section{Appendix A Survey and Interview Questions}

\section{Survey Questionnaire}

1 . What is your gender?

- Male

- Female

2. What is your age?

- $21-25$

- $26-30$

- $31-35$

- $\quad 36-40$

- $41-45$

- $46-50$

- $51-55$

- $56-60$

- $61+$

3. What is your current workplace?

- The Hong Kong Polytechnic University

- The Education University of Hong Kong

- The Chinese University of Hong Kong

- The University of Hong Kong

- Hong Kong University of Science and Technology

- The City University of Hong Kong

- The Baptist University of Hong Kong

4. What is your current position at the University?

- Instructor

- Senior Instructor

- Teaching Fellow

- Lecturer

- Senior Teaching Fellow

- Senior Lecturer

- Associate Professor

- Assistant Professor

- Professor

- Other (please specify)

5. What is your total number of years teaching experience?

- $1-5$ years

- 6-10 years

- $11-15$ years

- $16-20$ years

- 21-25 years

- $25+$ years

6. How often have you engaged in the following professional development activities during your professional career?

\begin{tabular}{|l|l|l|l|l|l|}
\hline & $\begin{array}{l}\text { More than 3 } \\
\text { times a year }\end{array}$ & $\begin{array}{l}2-3 \text { times a } \\
\text { year }\end{array}$ & $\begin{array}{l}\text { Once every } \\
\text { year }\end{array}$ & $\begin{array}{l}\text { Once every 2- } \\
3 \text { years }\end{array}$ & Never \\
\hline $\begin{array}{l}\text { Conducting } \\
\text { action research } \\
\text { into ICT skills }\end{array}$ & & & & & \\
\hline $\begin{array}{l}\text { Attending } \\
\text { conferences, }\end{array}$ & & & & & \\
\hline
\end{tabular}




\begin{tabular}{|l|l|l|l|l|}
\hline workshops, & & & & \\
seminars or \\
courses in ICT & & & & \\
skills. & & & & \\
\hline Reading & & & & \\
professional & & & & \\
literature & & & \\
involving ICT & & & & \\
(e.g. journals, & & & & \\
evidence-based & & & & \\
papers, thesis & & & & \\
papers). & & & & \\
\hline Sharing good & & & & \\
teaching & & & \\
practice (e.g. & & & & \\
mentoring, & & & & \\
informal & & & \\
dialogue, lesson & & & & \\
planning, peer & & & & \\
observation etc) & & & & \\
in use/adaption & & & & \\
of ICT with & & & & \\
colleagues. & & & & \\
\hline Participating in & & & & \\
a network of & & & & \\
teachers formed & & & & \\
specifically for & & & & \\
the professional & & & & \\
development of & & & & \\
teachers in ICT & & & & \\
skills & & & \\
(Community of & & & & \\
Practice). & & & & \\
\hline
\end{tabular}

7. Anything you would like to add about professional development in relation to ICT?

8. If you would like to participate in a follow-up semi-structured interview (approximately 30-40 minutes) to discuss the results and implications of the questionnaire please leave your contact information (Name, University, Position, Email)

\section{Guiding Interview Questions}

- What are the most recent PD in ICT activities you have participated in?

- Why did you participate in these activities?

- How useful have these activities been to enhance your teaching?

- What type of PD do you think are useful in helping you use ICT in your teaching?

- Have any PD activities changes your attitudes and beliefs in integrating ICT in your teaching? 